\title{
Ristipuud Lõuna-Eesti matusekombestikus
}

\author{
$\underline{\text { Marju Kõivupuu }}$
}

\section{Traditsiooniline Lõuna-Eesti matus}

Võrumaa Hargla, Karula, Kanepi, Urvaste, Põlva, Rõuge ja Räpina kihelkonna ning Tartumaa Sangaste, Kambja ja Võnnu kihelkonna traditsioonilisse matusekombestikku kuulub iseloomuliku rituaalina risti puusse lõikamine lahkunu viimsel teekonnal kodust (või ärasaatmispaigast) kalmistule. Seda, et Põhja-Eesti matusekombestikuga võrreldes on ajaloolise Võrumaa matusekombestik tunduvalt rituaaliderohkem, on täheldanud ka Võrumaa inimesed ise: LõunaEestin edimene asi - süümä! Meheveli oll Põltsamaa kandin, sääl es ole üldse midagi. Ku surnut vällä tõstetas - siin andas torti ja viina. Sääl tull rahvas täpselt, kotoh mingisugust üritust es olõq, lugija muiduki oll, aga säänest süümist ja juumist nigu siin... Nüüd nakas veidü lihtsamas minemä, rahval ei olõ raha ka nipallo käen. - MK: Kas valvman ka õks viil käüdäs? - Viimätsel aol ei oló inämb käünüq, mõni aasta autoga kävvemi õks, sääl sis laulti, olti vaiksõlt, pakuti pits ja... (80aastane S. Mõksi M. Kõivupuule < Rõuge khk., 1995)

Põhja-Eestis võeti matustele kaasa lillekimp või pärg, Lõuna-Eestis kindlasti tort, küpsetis, kook või midagi magusat söödavat. Lilled muidugi ka või pärg. (RKM II 467, 207/8< E. ja H. Mändmäe, Rõuge khk., 1994)

Ristilõikamise tava on ainult üks osa traditsioonilisest Lõuna-Eesti matusest. Iseloomulik on veel toidu pakkumine vähemalt neli või viis korda. Üldjoontes näeb kogu kombetalitus välja niisugune. 3-7 päeva jooksul jõuab korraldada asjaomased formaalsused. Peres kehtib vaikusenõue, peeglidaknad kaetakse kinni. Mõnel pool Võrumaal (Rõuge, Hargla khk.) käivad tänapäevani sõbrad ja tuttavad (eelkõige naisterahvad) öösiti surnut valvamas ja laulmas. Lauldakse nii vaimulikke kui ilmalikke laule, sageli ka lahkunu lemmiklaule. Viimane öö enne matuseid oli/on lähimate omaste päralt. Surnule pannakse kirstu kaasa tarbeesemeid: näiteks kamm, taskurätik, nõel-niit, vaimulik lauluraamat või midagi lahkunu poolt soovitut või lähedaste arvates vajalikku.

Matused kestsid intensiivselt kolm päeva, passiivselt üks nädal. Tuttavad istusid ööd üleval, valvasid. Eelviimane ja üleelviimane öö tulid sugulased kokku, võeti töölt lahti. Kirstu pandi asjad kaasa: kamm, taskurätt; iga tütar pani ühe krooni, paberraha; vanasti pandi hõberaha. Üks ühik iga laps. Padja alla 3 kroonist rahatähte, kamm kõrvale, kumma käe alla - ei mäleta, taskurätt küünarnuki alla, varrukasse. Kummale poole...? Ei näidata seda võõrastele. Õed sehkendasid, kust mina tean. Need asjad peavad raudselt olema..... (A. Kiristaja M. Kõivupuule < Põlva khk., 1995)

Matusepäeva hommikul kogunevad kutsutud peielised lahkunu koju, kaugemalt tulnutele ning tähtsamatele külalistele (vaimulik või ilmalik matja, pillimehed, fotograaf jt.) pakutakse kerget einet ja pits alkoholi. Peielistel on lisaks lilledele või pärjale kaasas kodus valmistatud tort või küpsetised. Järgneb kodust ärasaatmine. Võimaluse korral on kirst avatud. Vaimulik või ilmalik matusekorraldaja peab asjakohase jutluse/kõne, soovijad (lähedased) jätavad lahkunuga hüvasti ta laupa või kätt hetkeks puudutades ja viimseid sõnu lausudes. Seejärel kirst suletakse, matuserongkäigus kantakse see autole, mis ootab koduväravas (talu piiril). Kirst koos lillede ja pärgadega asetatakse autole, peielistele pakutakse pits alkoholi ja magusat suupistet. Korraldajad korjavad kiiresti teelt kuuseoksad ja leinakuused, need pannakse samuti autole. Seejärel sõidab 
autode kolonn surnuaia poole. Esimene vastutulija - mees või naine (laps) saab vastavalt viinapudeli või tordi. Järgmine peatus tehakse risti lõikamiseks. Seal pakutakse samuti viina ja suupistet. Kui surnuaial enam toitu ei pakuta, jääb see viimaseks toidu pakkumiseks enne peielauda istumist. Surnuaial võidakse kirst veel korraks avada, kuid see pole reegel. Kirst on kaetud kodukootud tekiga. Kui peres enam kangast ei koota, on tellitud tekk selleks otstarbeks väljast, oskajalt inimeselt. Kui lahkunu on mulda sängitatud ja haud kujundatud, pakutakse surnuaia väravas jällegi napsi ja (magusat) suupistet, millest saavad osa ka need peielised, kes on ainult surnuaiale tulnud lahkunuga hüvasti jätma. Seda toitu koju ei tooda, vaid jagatakse laiali. Ja alles nüüd minnakse leinamajja pidulikule peiesöögile. Laual põlevad mustade lintidega seotud küünlad, koht on kaetud ka lahkunule. Vahel on asetatud lahkunule määratud nõud lauale kummulipööratuina.

Matustele ei võeta ühes lapsi, kui lahkunu pole olnud neile väga lähedane. Keeldu ei põhjendata, vaid küsimusele vastatakse retooriliselt "nii ei tehta", niisamuti kui ei peeta sobivaks avalikkuse ees oma emotsioonide äärmuslikku väljaelamist.

\section{Ristipuude traditsioon kaasajal}

Tähelepanelik inimene märkab Lõuna-Eesti (eriti Rõuge kihelkonna) teede ääres puid, mille tüvesse kas äsja või mõni aeg tagasi on lõigatud ristimärk.

Tänapäeval põhjendatakse Lõuna-Eestis ristilõikamise vajadust :

- usundiliste kujutelmadega. Risti lõikamine on tõrjemaagiline toiming: Kui surnut viidi, enne surnuaiale jõudmist esimese metsatuka juures lõigati rist puu peale. Siis surnu ei tulnud koju tagasi. Tuli ainult ristini ja sealt edasi ei saanud. (RKM II 396, 438 (36)< Võnnu, 1986) MK: Mida usuti või kõneldi, kui rist lõigati? AK: Hing kinnistati puu sisse, heal jääb puu sisse. Pahad ei tule koju käima. Risti tegemisega sa oled ikkagi austust avaldanud ta on ikkagi elus ja olemas, tema hea vaim on kinnistatud puu sisse. (A. Kiristaja M. Kõivupuule < Põlva khk., 1995 )

MK: Aga miks rist tehti? AL: No mina sain aru nii, et ta ei

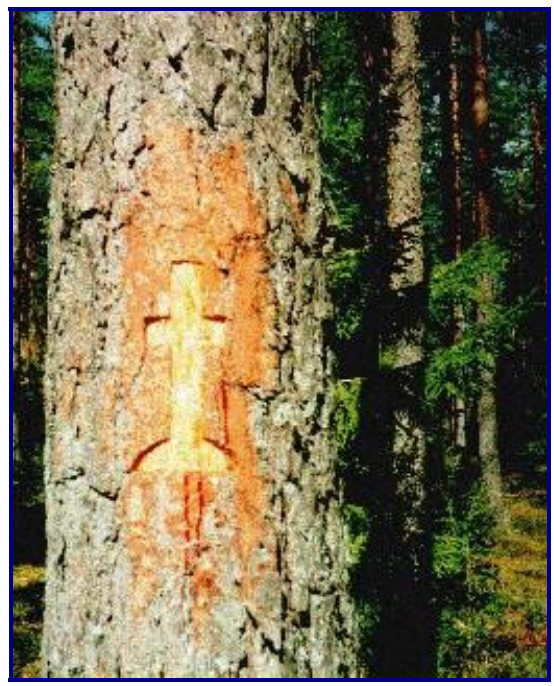
tuleks külastama, aga igas kihelkonnas on isemoodi. MK:

Nii et see uskumus on alles? AL: See uskumus on alles. Ja minu lell ei ole mind vaatamas käinud. Vaatamas käib ainult vanaema, aga ta on väga heasoovlik. (A. Leosk M.

Kõivupuule< Põlva khk., 1995)

Laatres on suur kõver puu. See oli umbes 10 aastat tagasi, matus oli Õru kandist. Tuldi autodest välja, otsiti puhas koht (männitüvel:MK). Redeliga roniti, noa ja peitliga tehti seda risti. Ei mäleta, et oleks pakutud midagi. Küsisin isalt, ma olin väike, umbes kümneaastane, et miks nad nii teevad. Isa seletas, et surnu ei saa koju tagasi tulla siis. (K. Ahk M. Kõivupuule $<$ Viljandi $1995<$ Sangaste khk.) Ema mul kõneles, et tõmmati rist puude pääle, kui siit Kastrest Võnnu viiti. Too olevat mingisugune usukomme, et sis läheb rutem taiva, ei jää maa sisse. Hakkab kodu käima ja unene näitama, ei saa magada. Tee kõvasti tööd, siis magad nagu jahukott, ei näe midagi. (RKM II 395, 445 (16)< Võnnu khk., 1986.) või

- lihtsalt vana tava järgimisega, kusjuures usundilised kujutelmad puuduvad (rist puusse lõigatakse kadunu mälestuseks, sest nii on seda alati tehtud). 
Ristiq tetäs praegu iks viil mälestuses puu sisse. Krõntspali mõtsah ja Pääsnä poolt tullen Hännimäel. Rong jääs saisma, kui lõigatas, ja sääl juvvas viina kah. Mõni puhterongi sisest lõikas too risti, inämbäst iks mõni sugulaisi. Iks alati om tood olnuq. (RKM II 22, 82 (12)< Räpina, 1949)

Ma ise tegin oma vanatädile. Tseremooniat ega põhjendamist polnud, lihtsalt iga surnurong teeb oma risti sinna ja kogu lugu. Ronisin onu õlgadele, see on niivõrd vana puu, sinna sai väga sümboolselt tehtud see rist, see puu on omadega õhtul. See võis 1987 olla. Vanatädi suri Elvas, maeti Laatresse. (K. Kornel M. Kõivupuule 1995/ 13(3)< Sangaste khk.);

- harvades teadetes, on öeldud, et rist lõigatakse puusse kohal, kus inimene(sed) on õnnetult surma saanud. Nendes tekstides pole sõnastatud usundilist kujutelma, mille kohaselt surnu hing asub elama õnnetuskohal kasvavasse puusse.

/ - - -/ Teisal on kirikust kaugemal rist puu koore sisse lõigatud, mõni kord ristile aasta arvgi juurde lisatud. Niisugusel kohal on mõni inimene surma saanud või mingisugune õnetus juhtunud. Rist peab niisuguse õnnetuse meelde tuletama. (E 8 o 14, 85 (247)< Räpina)

Kui õnnetult surma sai, siis sinna kohta tehti rist puusse või kivisse. (ERA II 282, 334 $(144)<$ Viljandi khk.)

Inimese hukkumispaiga tähistamine puusse lõigatud ristimärgiga ei ole iseloomulik ainult Lõuna-Eestile, sellekohaseid teateid on talletatud hajusalt kogu Eesti territooriumilt. Talupojad tõstnud Albu vallas mässu. Härra karistanud mehe surmanuhtlusega. Külast tulnud voorimehed. Mässu peamehed aetud regedele. Mehed röökinud mis hirmus, kuid see oli hilja. Jõutud Korba metsa vahele. Tapetud mehed ära. Omaksed korjanud laibad ära ja matnud maha. Teinud kuuse peale niimitu risti kui palju mehi surma saanud. (ERA II 220, 356/7 (6)< Järva-Jaani khk., 1939)

Sooniste mõisa läheduses asub ristiga mänd. Rist lõigatud puusse sulase mälestuseks, kes vankrile hüpates vikatisse kukkus ja surma sai. (ERA II 229, 189 (15)< Nissi khk., 1939)

Erinevalt soomlastest pole eesti traditsioonile iseloomulik lahkunu eluaastaid tähistavate daatumite lõikamine puutüvesse, seda on tehtud ainult harukorril.

Tänapäeval tähistavad liiklusõnnetuste ohvrite hukkumispaiku mälestuskivid või aiakesega piiratud platsid (üks selline asub Rõuge-Sännä teel), sinna viiakse värskeid lilli. Inimesed, kellele ristilõikamise tava on tundmatu, peavad värskeid riste teede ääres liiklusõnnetuse ohvrite mälestuseks lõigatuteks. (V. Kanniste M. Kõivupuule 1996< Vahtseliina khk.)

Ristipuude analooge leidub õigeusklike setude matusekombestikus. Setud asetavad ristipuu alla kõdunema lautsilauad, surnuõled ja surnuviha või põletavad need rituaalselt. Sellist puud nimetatakse lautsipuuks. Setumaal leidub kolmes kohas lautsisid, Seonini, Jatsmanni ja Lutepää külas. Kui inimene ära sureb, siis heidetakse sinna ôled, millel ta suri, kauss veega, millega surnut pesti, ja viht. Samuti ka üks kanamuna, et surnu sü̈̈a saaks, kui ta lautsile tuleb. Surma puhul lõigatakse lautsil ristid. Need puud on riste täis. Lautsid on pühad ja nende roojastamine on kõige suurem pühaduse teotamine.(E IX 19 (60)< Setu)

Suhteliselt hilise ajani (20. sajandi 30.- 40. aastad) on ristide lõikamise traditsioon olnud elujõuline ka Saaremaal Kihelkonna kihelkonnas. Puuliikidest on eelistatuim olnud mänd (7 teadet). Kaheksast arhiiviteatest seitsmes on öeldud, et rist takistab surnu koduskäimist. Praeguse Kiirassaare küla piirkonnas Oitma põllu käänu juures olid jämedad männid, kuhu 
lõigati riste, mis pidid surnute hinged kinni hoidma. Kui matuserong oli mööda läinud, lõikas üks matuselistest koore sisse risti. Seda kohta kardeti õudsel kombel. [---] Männid võeti maha Eesti iseseisvuse ajal, kui anti välja seadus, et maanteede ääred olgu lagedad. Üks jäme, tihedalt riste täis männitüve jupp lebas veel kaua maantee ääres üksinda. Muuseumi ta vist siiski ei jõudnud. (RKM II 205, 384/9< Kihelkonna)

Erinevalt Lõuna-Eestist puuduvad siin teated rituaalsest viinavõtmisest, küll aga on Kihelkonna kihelkonnas ristimärgile lisatud peremärk (kaks arhiiviteadet), mis muutis ristipuu kohalikele elanikele oluliselt informatiivsemaks (vt ka E 17 998< Kihelkonna): Kui sa Kihelkonnalt tuled, siis seal oli tie ääres 2-3 puud, kui surnud maha viidi, siis tehti sinna puude peele ristid, siis õuemerk oli ka ning 3 risti tehti. Männapuud olid. (ERA II 164, 363 (19)< Kihelkonna < L. Köögardal 1937)

Lõuna-Eesti traditsioonist erineb ka tehtavate ristide arv. Kaheksast teatest kahel juhul on öeldud, et riste tõmmati kolm, paaril juhul on sõnastatud ebaselgelt - Surnuaiale surnuga minnes tõmmati ristid puudele - suure männale, siis ei tule surm koju tagasi. Seda tehti umbes 30 aastat tagasi. (RKM II 73, 416 (31)< Kihelkonna, 1958) - , mis laseb oletada, et riste tehti rohkem kui üks.

Kahes teates on öeldud, et rist tehakse pärast surnuaialt tulekut. See erineb Lõuna-Eesti traditsioonist, kuid on analoogne lätlastega : Atla ja Kala tee ääres Kihelkonna tee ääres on ristid puude sisse lõigatud. Mõni on väike puu, teine on suur. Need puud on täis ristisid. Mõni nii täis, et ei enam ruumi. Need ristid tehakse pärast surnumatmist, kui surnuaialt tagasi tullakse. Arvatakse, et siis surn(u) ei hakka kodu käima. Surnu tulle sedasama teed mööda koju, kust ta surnuaiale viidi. Ristide juurde on veel õuemärgid pandud [---] saab teada, kui mitu surnut kellegist talust maetud. (E 17 998< Kihelkonna)

Lisaks ristide lõikamisele on Saaremaal kodukäijate tõrjeks ja perest surma eemalepeletamiseks praktiseeritud ka puulatvade murdmist: Kureveres murtakse männad tee ääres pooleks, siis (tule) ei surnu koju. (E 17 99< Kihelkonna). Murtud latvadega mände (puid) on nimetatud virvepuudeks (RKM II 2, 96 (60) < Kihelkonna, 1947) ja neid jälgides on otsustatud, kuidas läheb surnul teises ilmas (Kihelkonna khk, Mustjala khk, Karja khk., Kärla khk.): [Latv murti noorel männil] Kui mänd sellepeale ära kuivanud, siis olla surnul sant olla, aga kui puu lopsakalt kasvama jäänud, siis olla surnul hea olla. (ERA II 275, 379 (52)< Mustjala, 1940) või sugulastel siin ilmas: Surmaga minnes murti puude latvu (Abaja metsas). Pärast vaadati kas see puu hakkas uusi võsu ajama või kuivas ta ä̈̈. Kui ajas võsu, oli ses sugus sigimist loota. Kui aga ää kuivas siis pikapääle lõppes ka see sugu. Neid murtud latvadega puid (männid) hüüti virvepuudeks. (RKM II 2, 96 (60) < Kihelkonna, 1947)

[---]Surnuajareisil oli oma kindel koht, kus iga matuserong kinni pidas. See oli Paatsa metsas. [---] Sääl murti kolmel noorel kuusel ladvad maha. [---] Siis vaateti pärast, kudas nee kuused uiest kasuma akkasid. Kui lihavast kasusid, siis arvati, et murdijal läheb pärast elus kenast, kui aga ää kuivab või kiduraks jääb, siis pidade jälle murdijal omal niisama sitast minema ka. (ERA II 227, 29879 (2)< Karja< Mustjala, 1940)

Lisaks Saaremaa Kihelkonna kihelkonnale on kreeka ja andrease ristide baasil kujundatud (pere?)märke lõigatud puutüvesse Viljandimaal Helme kihelkonnas: Üksik tähtjas kuusk maantee ääres, keda rahvas "risti kuuseks" nimetasid, oli ristisid täis leigatud, sääl pidasid 
surnomatjad kinni, jõid äräläinud mälestuseks mõne lõngso viina, ülendasid hinge ja alandasid pattu ja leikasid kuuse koore pääle ristisid nuaga, edaspidiseks mälestuseks. (EKS 4o 3, 323/4 (66)< Helme, A. Vahlberg, sünd. 1860; sama ERA II 198, 484 (71)< Helme)

Erikujuliste ristide tegemisel on taotletud suuremat informatiivsust eelkõige lahkunu omastele. Erikujuline, individuaalne (risti)märk võimaldas oma puud hiljem kergemini ära tunda.

Karksi kihelkonnast pärinevas arhiiviteates on öeldud, et ristid on raiutud kivisse. [---] Rootsi talu kottal /Karksis/- seal juures kaks kivi - kui surnuga mööda minti, raiuti sinna kivi pääle rist 1-2 meest ragosiva nüri kirvaga. Kõik seisva paigal. Naised sõidukitelt maha ei tulnud. (ERA II 78, 129 (73)< Karksi)

Lisaks eeltoodule on üksikuid teateid ristide lõikamise kohta Pärnumaalt Tori, Saarde, Halliste ja Karksi kihelkonnast, Viljandimaalt Helme, Tarvastu, Kõpu, Viljandi, KolgaJaani, Suure-Jaani ning Põltsamaa kihelkonnast, Virumaalt Iisaku ja Haljala kihelkonnast ja Tartumaalt Nõo kihelkonnast. Käesoleva sajandi teisel poolel nimetatud kihelkondadest täiendavat materjali pole juurde laekunud. Ott Kaasiku suuliste andmete põhjal pole traditsioon ka Helme kihelkonnas hääbunud. (O. Kaasik M. Kõivupuule 1994)

Ristide lõikamise traditsioon oli tuntud ka Põhja-Lätis, mis on olnud ajalooliselt eestlaste asustusala ning praktiliselt kuni Eesti Vabariigi sünnini 1918. aastal ühine kultuuriruum Liivimaa. Eiseni järgi (Eisen 1920: 57) on Võnnu (Cesise) maakonnas olnud mänd, kuhu matuselised lõikasid risti surnuaialt tulles surnu koduskäimise tõkkeks. Vilkuna (Vilkuna 1992: 58) on kasutanud võrdlusülevaate saamiseks Eiseni materjali ning kahte informanti: K.Arajst Riiast ja K. Straubergsi Rootsist, kelle andmetel on rist kalmistult tagasiteel lõigatud põhjendusega, et surnu leiaks viimsel kohtupäeval tee koju. Rist puul osutanud ka sellele, et seda teed on kalmitule viidud kristlane. Kui lahkunu oli naine, lisati ristimärgile riideribasid (Valka lähedal tehtud koguni kangaribadest lilekimbuke) ning kollaseid ja punaseid lõngu. Ristilõikamise juures joodi õlut või puskarit, viimast piserdati ka maha ning järelejäänud õlu ohverdati puu juurtele. Rituaal sooritatud surnu koduskäimise tõkestamiseks. (Vilkuna 1992: 58) Vicijemest pärit kirjaniku ja ajaloolase A. Goba andmetele tuginedes saan lisada veel järgmist. Kõige sagedamini kasutati pühi mände, harvemini teisi puid. Kui matuselised sõitsid koju kalmistult, peatusid nad tavaliselt teeäärse püha männi (või kuuse) juures, lõikasid puu koorde risti, harvemini ka aastaarvu ja kuupäeva. Seda tehti maagilistel eesmärkidel - et surnu ei tuleks koju tagasi ja ei tülitaks elavaid.

Smiltene lähedal kasvas kunagi vana mänd, mis kuivas ära sõjajärgsetel aastatel. Ka selle männi juures peatusid sageli matuselised, lõikasid puu koorde risti, aga mõnikord pidasid isegi väikese söömingu - võtsid veidi toitu ja napsi. Sellist pärimust tean Smiltene ja Trikata ümbrusest, aga see traditsioon on tuntud ka mujal Lätis. (A. Goba kiri M. Kõivupuule 30.03. 1995)

A. Goba informatsioonile tuginedes on põhjalätlased raiunud maagilisi märke (peremärke) ka kivisse, millega püüti surnute hingi siduda surnute ilmaga. (M. Kõivupuu ekspeditsiooni materjalid Vicijemesse mais 1990) 


\section{Ristimetsad ja ristipuud}

Iga eelnimetatud Lõuna-Eesti kihelkonna teedel on välja kujunenud oma traditsioonilised ristilõikamise kohad, kas ristimetsad, küla ristipuud või individuaalsed (pere)puud. Isegi see, et tänapäeval pääseb surnuaiale sageli ainult tiheda liiklusega magistraali mööda (nt. Tartu-Võru mnt., Võru-Valga mnt. jne.), pole suutnud traditsioonile hävitavalt mõjuda. Seega väide (Virtaranta 1991: 50), nagu ohustaks (oleks ohustanud) tsivilisatsiooni areng - autode kasutuselevõtt ja kiirustamine kõikjal - ning kõiges seda vana tava, ei pea esialgu veel paika. Matusetseremoonia on üks paljudest siirderiitustest. Matuste käigus irrutatakse surnud inimene elavate ilmast ja siirdatakse surnute ilma ning sooritatakse mitmeid tõrjemaagilisi toiminguid surnu koduskäimise tõkestamiseks ja elavate julgeoleku tagamiseks.

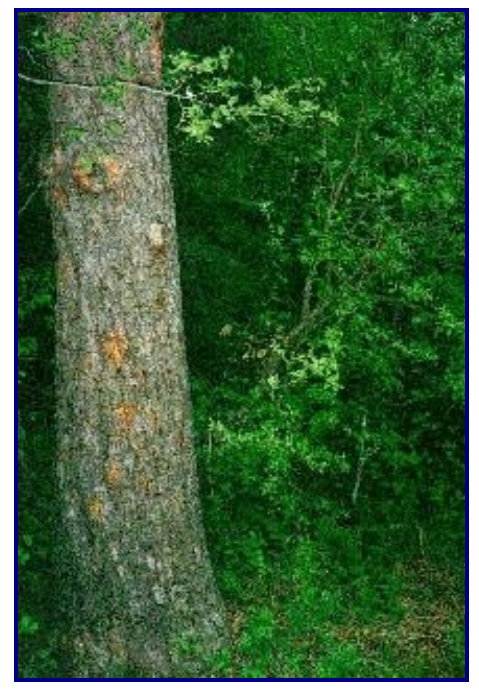

Ristipuu asukoha valik sõltub küll maastiku iseärasustest, kuid üldjuhul markeerib see teadlikult või alateadlikult piiri, millest üleviiduna jätavad lähedased temaga lõplikult hüvasti - nüüdsest on ta elavate hulgast välja arvatud. Selliseks piiriks on kas talu, küla või ka kihelkonna piir. Ristilõikamiseks tehtud peatus on omaste keskel viimane enne lahkunuga lõplikku hüvastijätmist kalmistul, kuhu tulevad jumalaga jätma ka need, keda mingil põhjusel peietele pole kutsutud.

\section{Ristimetsad asuvad kas}

- surnuaia vahetus läheduses (Hargla ristipalu Võru-Valga mnt. ääres Saru poolt tulles, Tõrvapalu ristimets Rõuge JaaniPeebu kalmistu juures, Põlva Sulednu(o) männik Põlva surnuaia juures Rosmal, Räpina surnuaia lähedal jne.) või

- nn kirikuteel, küla ja surnuaia vahele jäävas metsatukas (Sastavi, Rauskapalu ja Piirivariku ristimetsad Urvaste kihelkonnas, Viirapalu kuusetukk Rõuge kihelkonnas, Varstu Pilpaküla metsatukk Rõuge kihelkonnas, kaseallee Matsil teel Vana-Roosa surnuaiale, Asuvarik Kanepi kihelkonnas jne.): [---] Siin on oja ja siin on mets nagu näed. See on Asuvarik, ja selle metsa viimane sopp oli ristipuude koht. Kui nüüd surnurong või matuserong siit külast läks Kanepi poole, siis seal metsa ääres peatati, ja lähemad omaksed lõikasid, see oli kuusik, lõikasid kuuse tüvesse risti selle surnu mälestuseks. (Virtaranta 1991:49)

Ristimetsad on okaspuumetsad (männikud, kuusikud) või segametsad. Iseloomulikult on puudel rohkem kui üks rist, sealjuures püütakse lõigata lähedaste ristid samale puule (Põlva, Rõuge). Siin ommaq Plagikülä rahva ristipuuq. Ütel puul omma Saarõmõtsaq ja Toomõq mäledamatu aost. Tõnõ (puu kõrval) omma Oruq ja Ivaski. Tõsõq Aruq omma kolmanda puu pääl. (J. Toom M. Kõivupuule 1995< Põlva khk.)

Nooremad inimesed, kelle jaoks rituaali tähenduslikud nüansid on jäänud kaugeks, püüavad risti lõigata puusse, kuhu on juba mõni rist lõigatud.

Küla ristipuudeks on üldjuhul vanad männid (Korgõpalu ristipettäj Rõuge kihelkonnas, Laatre ristimänd Sangaste kihelkonnas, ristimänd Viitina-Rõuge teel Rõuge kihelkonnas, ristipettäj Kellamäe sookaitseala alguses jne) või suured lehtpuud (igipõlinõ ristikõiv MatsiVana-Roosa tee ääres, Mustahamba küla tamm - mõlemad Rõuge kihelkonnas jne.): 
Mustahamba tamm. Asub mäekünka nõlval, vanus umbes 450 aastat. Puul olen lugenud ca 44 risti - Mustahamba küla lahkunud inimeste mälestuseks. Ma täpselt ei mäleta, kuna lõigati rist puu tüvesse, koorde, kuni puiduni - suur, sügav, lausa valutegev. "See tamm on meie küla igikestvuse sümbol," ütles külavanem umbes 25 aastat tagasi. (H. Parts 1996. a. M. Kõivupuule)

Reeglina asuvad sellised puud külast surnuaia poole viival esimesel teeristil või mõne külast kaugema risttee vahetus läheduses ning selline ristipuu on piiriks koduringi ja (vaenuliku) välisilma vahel.

Individuaalsete (pere)ristipuude valikul on osutunud määravaks:

- usundilised kujutelmad. Rist (või isegi mitu risti) lõigatakse puusse koduskäimise tõrjeks. Vilkuna (Vilkuna 1991: 10) väidab, et Kagu-Eestis tehakse ristid ainult sellepärast, et see on vana tava, st. usundilised kujutelmad on kadunud. Tänapäevase Kagu-Eesti materjali hankimiseks on Vilkuna kasutanud eelkõige eksiilis elavaid haritlasi (R. Kolk, V. Uibopuu) või kodu-Eesti intelligentsi esindajaid (P. Viires, P. Lehestik, K. Kama). Ilmselt sellest siis ka ühekülgselt üldistavad järeldused.

Kuigi väliselt ju ei erine tõrjemaagilistel eesmärkidel tehtud ristid puudel lihtsalt mälestuseks lõigatud ristidest, asuvad tõrjemaagilise pärimusega seotud ristipuud eelkõige tihedast asustusest kõrvale jäävates metsakülades või üksiktaludes (Hargla, Rõuge, Põlva khk.), kus elavad vanad inimesed (60 ja vanemad), kelle mõtteilmas ja argielus on siiani kindel koht uskumustel kurjast silmast, kodukäijatest, sõnamaagiast jne. Traditsioonilise mõtteviisi osalist või täielikku säilimist on soodustanud seal kahtlemata majanduslik mahajäämus, isoleeritus suurematest asulatest, massikommunikatsioonivahendite puudumine hilise (1970.-1990.) elektrifitseerimise tõttu või elektri puudumine tänaseni. Olen vestelnud ka kõrgema haridusega inimestega, kes otseselt surnu koduskäimise võimalust eitavad, aga ebamäärast sõnulseletamatut usndilist nüanssi toimingu juures siiki tunnistavad.

Kats kõivu oll, sinnaq lõigati. Mu esäle lõigas Pärnä Volli, lepä sisse lõigati. Järgmine tetti kuusõ pääle. Vaimu omma vihatsõ, ku ristita jääs. Piiri pääle tetäs, pakutas viina ja torti. Mõtsavaht Vetalõ tehti vahtrõ pääle, et vanal mehel om Rõugõst pikk maa tullaq. (RKM II 467, 257/8 (1) < E. M. Bergmann, Rõuge khk., 1994)

Metsavahti peeti kurja silmaga inimeseks, ja et ta ikka tõesti koju ei pääseks paha tegema, tehti kalmistuteel korduvalt riste. See matus olnud 1993. aastal.

Sinna, kuhu rist puu pääle tehti, surnu ei hakka kodus käima nüüd saab ainult ristini. Nii tehti ka kuuse ja kase peale.

(EKRK I 92, 64< August Tolm< Rõuge khk., 1991)

Ega esiq enäb ei tiiäq, mille. A küll ta esiq (kooluq) teab, kus ja kelle rist on. (EKRK I 89, 29 (14)< A. Kikas< Hargla khk., 1990)

- traditsioonide austamine ning väärtushinnangute järjepidevuse säilitamise vajadus nõukogude perioodil, mil sotsiaalsed muutused ühiskonnaelus paiskasid segamini senise elukorralduse külaühiskonnas.

J. Vilkuna väidab, et ristilõikamise traditsioon Lõuna-Eestis on iseloomulik maal elavatele luterlastele, setud, venelased ja

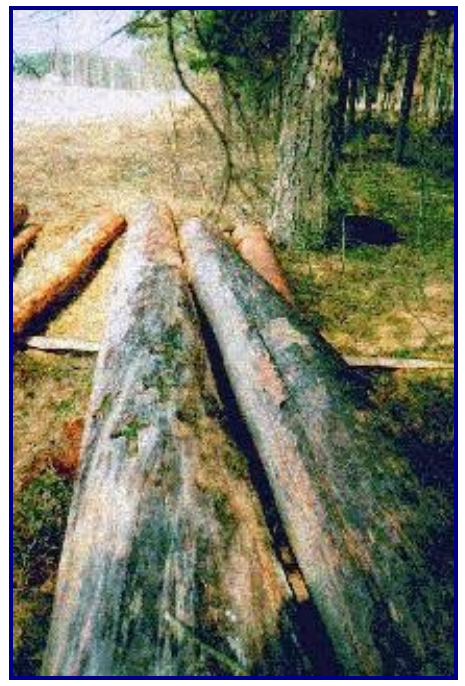


ristimata inimesed tava ei järgi. (Vilkuna 1992:56-57) Setu ristidega lautsipuudest oli eespool juba juttu.

Nõukogude korra kehtestamisega katkesid eestlastel kirikuga normaalsed suhted 1950 ja hiljem sündinud lapsi ristiti minimaalselt, kiriklike kombetalituste osa vähenes järsult. Sagenesid ilmalikud matused, paralleelselt kiriklike surnuaiapühadega hakati ametlikult pidama ilmalikke. Kirikuga suhtelmise puudumisest tingitud tühjale kohale tekkisid uued tavad, näiteks jõululaupäeval kalmistutel küünalde süütamise traditsioon jne.

Kuigi ristilõikamise traditsiooni võib tänapäeval tõlgitseda ka kui kristlikku toimingut (Vilkuna 1991: 10), ei kuulu tava kiriklike talituste hulka, pigem vastupidi. Osa väljastpoolt Võrumaad tulnud pastoreid on tava tauninud ning nende eest on ristilõikamist isegi varjatud. Nõukogude perioodi ilmalike matuste korral käsitasid inimesed ristilõikamise rituaali kui kirikliku talituse teatavat kompensatsiooni, seda enam, et sellesse traditsiooni suhtusid halvustavalt ka mujalt sissetulnud juhtivtöötajad (parteisekretärid, ateistlikust vaimust kantud kooliõpetajad jne.).

See, kas lahkunu või tema lähemad omaksed on ristitud või mitte, pole kaasajal antud kontekstis omanud tähtsust ja rist(id) lõigati ka siis, kui oli tegemist ilmaliku matusega. [---] 4-5 aastat tagasi matsime ema, siis peeti kinni ja tehti nii. Mehe võtsiva noa vällä ja paar tükkü ja lätsiva ja naersiva veel, et kui metsavaht nü̈̈d tule. Leevakust teine mets Räpina poole on see, pahema käe pool, rist on 15-20 cm. (RKM II 347, 143< Leida Häidson< Räpina khk., 1980)

Üldjuhul on kohalikud vanemad kirikuõpetajad ristilõikamise traditsiooni suhtunud kas neutraalselt või võtnud ka ise toimingust aktiivselt osa, põhjendades oma käitumist kohalike tavade ja seega ka surnu soovide respekteerimisega: 1979. aastal oli matus Valga linnast Hargla surnuaiale. 89- aastane lahkunu oli pärit Saru külast, kus ristilõikamise tava kuulub tänaseni matusekombestikku. Hargla kirikuõpetaja küsis noorukeselt matusekorraldajalt, et "kas ti risti ka iks lõikat" ning oli mures, et Valga poolt tulles ei jää teele sobivat kohta. Muuhulgas pole tava ka Harglast Valga poole edasi levinud. Kirikuõpetaja abiga sai koht siiski leitud ja rist puusse lõigatud, kusjuuures eirati nõuet, et naisterahval ei ole sünnis risti lõigata. (M. Kõivupuu perepärimus)

Taunivalt suhtuvad traditsiooni tervikuna reeglina need kirikuõpetajad, kes pole kohalikud ning kes mingil põhjusel pole ületanud distantsi koguduse (vanemate) liikmetega. Vanaema oli Põlva abikiriku koguduses. Seda juhatas [---]. Tema elas Tartus ja Tallinnas, tema ei tulnud ligi, et see on ebausk. Enne oli [---], tema soosis rohkem. Arvas ka, et on ebausk, aga ei keelanud. Kirikuõpetajale prooviti ka napsi pakkuda, aga tema viisakalt keeldus. (A. Kiristaja vanaema mälestuste põhjal M. Kõivupuule< Põlva khk., 1995)

Kui oli võimalik, lõigati rist nõukogude võimu poolt võõrandatud kodutalu piirile. Selle toiminguga väljendati põliste traditsioonide austamist ning omalaadset vaikset protesti vägivaldse ja võõra ühiskonnakorralduse vastu.

Kolhoosiaegne matus, siis peeti vana talu piiri peal kinni ja tehti ka rist, siis ka kui oli ilmalik matus. See, kes surnuga kaasa sõitis, see teadis. (RKM II 467, $206<$ E. ja H. Mändmäe, A. Tuusis, Rõuge khk., 1994)

Talumees kanti kätel oma talu piirini, seal tehti suurte puude peale rist, et ta ei tuleks kodu 
tagasi. (RKM II 467, 372/3 (3) < K. Kornel, Rõuge khk., 1994)

No vat tema tuudi toda Leevi tiid müüdä vällä vai sisse sinnaq Põlvahe... sis vist tetti uma mõtsa puu pääle. Tuukõrd viil uma mõts es olõq... Aga nü̈̈d sai tagasi. (V. Saaremets M. Kõivupuule 1995< Põlva khk.)

\section{Ristilõikamise rituaal}

koosneb:

- ristipuu valikust;

- risti lõikamisest;

- rituaalse viinapitsi ja suupiste pakkumisest.

Ristilõikamise rituaali ettevalmistavasse etappi kuulub ristipuu valik. Kui on traditsiooniks, et igal lahkunul on oma ristipuu, (Urvaste khk., Hargla khk. ), siis sellisel juhul vaadatakse puu juba päev-paar varem valmis. Ristipuu peab olema esteetiline - ilus ja elus puu ning maanteele hästi ära paistma. Kui on vähegi võimalik, püütakse puu valida nii, et näiteks abikaasade ristid satuksid kõrvuti puudele. (Hargla khk.) Vajadusel kärbitakse kõrvalasuvate puude oksi. Liigiliselt on eelistatud mänd, kuusk ja kask, harvemini tamm, vaher või lepp. Küla ühise ristipuuna on vaieldamatult eelistatuim mänd (pettäj) (Korgõmäe pettäj Rõuge khk-s, Viitina pettäj Rõuge khk-s; Kellämäe pettäj Rõuge khk-s, Laatre ristimänd Sangaste khk-s jne.), harva kask (Rõuge khk.) või tamm (Rõuge khk-s)

Mänd vastab paremini ka esteetilistele nõuetele. Männikoorde lõigatud rist püsib kaua ilus ja vaadeldav, seevastu kui kuusetüvesse lõigatud ristid jooksevad ohtralt vaiku ja armistuvad ebamäärasteks kujunditeks. Ka kasetüvesse lõigatud rist armistub suhteliselt ruttu.

Ristiq piassi olõma. Kuusõ külge lõigatas. Kuus nakas vaiku ajama, ilustõ tulõ lõigada, sis jääs nätäq. Tuu kommõ ei olõq kaonu. (S. Mõksi M. Kõivupuule 1995< Rõuge khk.) Liinamäe rahvas maetas Urvastõ surnuaida. Ku surnu viiäs Urvastõ mõisa kaudu, peetäs Rauskapalu mõtsa vahel, vana Liinamäe valla piiri pääl matussõrong kinniq ja lõigatas pedäjä vai kuusõ tüve sisse rist. Üte puu sisse kattõ risti ei lõigata, tuuperäst om säämtse ristipuu otsmine, mis tii pääle häste är paistus, küländ rassõ, tuu tüü tetäs joba eelmine päiv ärq. (E. Saar M. Kõivupuule 1995)

Sastavis märkasin peamiselt kuuskede puhul, et mõnel kuusel olid mõned oksad vaid selleks ära lõigatud, maha raiutud, et puutüvele ruumi muretseda risti tegemise jaoks, rohkem ma kombetäitmise huvides puude laasimist ei märganud. (RKM II 47, 297< E. Siil, 1955)

Kui juhtub, et kogemata asutakse risti lõikama juba surnud või kuivama hakkava puu tüvesse, jäetakse toiming pooleli ja valitakse uus puu. ( M. Kõivupuu, Hargla khk., 1989)

Paiguti on siiani püütud kinni pidada nõudest, et meessoost surnule lõigatakse rist okaspuusse ja naissoost surnule lehtpuusse.

Surnurong sõitis, hakkajam mees lõikas risti puusse. Meesterahvale oli okaspuu, naistele lehtpuu. Tavaliselt lõigati ikka okaspuussse. [---] (EKRK I 92, 259< M. Mõistus < Hargla khk., < Urvaste khk., 1991)

Kui pole mingil põhjusel enam võimalik traditsioonilisse kohta risti lõigata, tehakse rist mõnesse vähemsobivamasse puusse või pannakse alus hoopis uuele ristimetsatukale (puule), risti lõikamata ei jäeta. Sännä-Rõuge teel asub vana kuivanud ristimänd. Kuna sellesse puusse enam riste lõigata ei saa, on hakatud ümbruse mändidele riste tegema. Vaid Matsi vana ristikase (Rõuge khk.) ladvaosa ulatub uuele teele, ristid lõigatakse nüüd uue tee äärde 
noorele kasealleele.

Vahtrõ pääle tetti. Ristipedäja saag Kerigumõtsa mõtsavaht mahaq. Mehe rist om

Tõrvapalun. (RKM II 467, 199 (2)< Lapi Koidu< Rõuge khk., 1995)

Kõosaarde oll ka mitu risti tett, ei olõ jo puid, talupiiri es saaq tetäq! (Perek. Jõed< Rõuge khk., 1995)

[---] Praegu mahamurdunu kõiv, kohe rist lõigati. (Võ̃̃ra maa pääle 3 km kotust. Es olõq ilosat puud võtta.) (J. Toom M. Kõivupuule. Selgitus kodukandi ristipuude skeemile. < Põlva khk., 1995)

Risti lõikab puusse lähem(ad) meessoost sugulane(sed), kes võimalusel sõidab surnuautol kaasa. Nn. õiges kohas surnurong peatub.

Egale inimesele tetti iks puu külge rist. Kui läbi mõtsa viidi ja mateti. Kes kõõge sugulamb oli, see lõigas. Kas pojaq või väimeheq. Meesterahva iks lõigassiva! [---] Kõik seisva niikavva kui rist tetti, siis istsiva pääle ja sõidiva edesi. (ERA II 63, $231(2)<\mathrm{Kambja)}$ Risti lõigassivaq ristipojaq, kes kannuq kah risti. (J. Toom M. Kõivupuule< Põlva khk., 1995)

Mehed võtavad mütsid peast, toimingut jälgitakse vaikides. Põlva ja Kanepi kihelkonna traditsiooni on kuulunud samaaegne kirikukellade helistamine. (A. Leosk M. Kõivupuule 1995 < Põlva khk.) Üldiselt oskavad pika staazhiga kellamehed hinnata kauguse ja aja kulu suhet ning teavad ilma matusekorraldaja poolt sõna saatmatagi, millal läheneb surnurong kalmistule ja hakkavad ise õigel ajal kelli helistama.

Missuguse kuju rist võtab, oleneb lõikaja kunstimeelest ja osavusest, aga ka usulisest kuuluvusest (üksikuid vene riste võib leida Hargla, Rõuge ja Põlva kihelkonna ristipuudelt). Enamlevinud on lihtsad ladina ristid, nn. kannatusristid, mida sageli on kujutatud koos ristalusega (kääpaga). Tunduvalt harvem kohtab kreeka ja andrease riste. Tänapäeval pole enam täheldatud, et risti lõigatakse koorest puhastatud suuremasse sälku, kui seda risti tegemiseks vaja läheb. See sarnaneb soomlaste vastava traditsiooniga, kus puutüvesse lõigatud sälku on märgitud surnu sünni- ja surma-aasta ning kuhu mõnikord on lõigatud ka ristimärk. (Vilkuna 1992: 45) Selliseid tähelepanekuid on Põlva Sulendu ristimetsas teinud R. Viidalepp 1931. aastal (ERA II 36, 143-176). Samas Viidalepa kogus leidub mõningaid riste, millele on lisatud lahkunu nimetähed.

Ristid jäävad puudel enam-vähem lõikaja/vaatleja silmade kõrgusele. Kuid siingi oleneb kõik olukorrast. Kui on tegemist küla ristipuuga, kus mitukümmend risti ees, tehakse rist vabale kohale, nii suur või väike nagu võimalik. [---] Kui autoga sõideti, sis seisti autokatusele, et saaks kõrgemale lõigata. Rist lõigati mälestuseks ja, et tagasi ei tule enam. (RKM II 392, 30 (3)< Kambja khk., 1985)

Laatre ristimännil on arvukalt riste umbes kolme meetri kõrguseni (loendasin neid üle saja, siis läks arvepidamine sassi), osa neist tõmmatud kriipsudena, osa hoolikalt lõigatud-uuristatud, ladina ristid 10-20 cm kõrged, kreeka või andrease ristid teinekord vaevalt $2 \times 2 \mathrm{~cm}$.

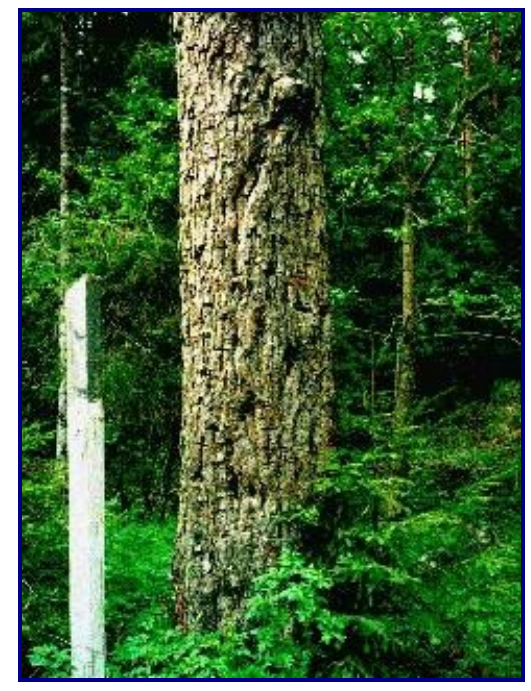


On rist valmis, järgneb rituaalne viina ja suupiste pakkumine. Matuselised ei tõlgenda seda kaasajal enam kui ohvritoimingut, vaid kui üht täitmist nõudvat kommet. J. Vilkuna teeb ainult Põlva ja Hargla kihelkonna traditsioonile tuginedes üldistuse kogu Lõuna-Eesti kohta. (Vilkuna 1991: 10) Enamlevinud on see rituaalne "pitsi pakkumine" ühes suupistega siiski ainult Hargla, Põlva, Kanepi ja Rõuge kihelkonnas. Sealjuures võib viina või magusa napsi suutäiest loobuda ja piirduda ainult magusa koogitüki või küpsisega. (M. Kõivupuu Hargla khk. perepärimuse põhjal.)

Ristitegemise juures joodi alati pudel viina ärq! (EKRK I 92, 122< Rõuge khk. $<$ A. Tolm, 1991)

Ja sel ajal kui neid riste lõigati, siis tavaliselt rändas viinapudel ka inimeste käes ringi käest kätte ja siis rü̈bati seal. Eriti muidugi talvel, kui oli külm. Aga ma olen kuulnud, minu koolivend ja naabrimees Aksel Mark, kes kirjutas mulle sellest hiljuti, ütles jaa, et viinapudel muidugi oli seal, et surnul ei hakkaks külm. [---] (Virtaranta 1991:49)

Viimastel kümnenditel on matusekorraldajad naised pakkunud alkoholi kaasavõetud napsiklaasidest. Perestroika ja M. Gorbatshovi alkoholipoliitika ajal (1980. aastad ) osalesin Hargla khk. peietel, kus nii ristilõikamise aegu kui surnuaial ja hiljem peielauaski pakuti alkoholi limonaadipudelitest ning korraldajad olid õnnetud, et napsi tuleb võtta labaselt, otse pudelist.

Mõned kirikuõpetajad on rituaalset akoholitarvitamist tauninud.

Innembide oll väega moodus, et surnurong peeti kinni, anti sü̈a ja lahkunu naps, a õpetaja rahuldas tuu maha. Nüüt enamp ei ole. Ainult rist tetas puu sisse. Ma ole matusel ollu küll, kui on tettü. [---] (RKM II 347, 236/7 (21)< Räpina khk. < L. Mõtsard, 1980) Kirikuõpetajale prooviti ka napsi pakkuda, aga tema viisakalt keeldus. (A. Kiristaja M. Kõivupuule < Põlva khk., 1995)

Kagu-Eesti tänapäevases traditsioonis üldjuhul ohvriande ristipuu külge ei seota. Põlva Sulendu ristimetsas märkasin 1996. aasta kevadel ristimärgi all musta paelaga kinnitatud pihlakaoksakest, Rõuge kihelkonna paari küla ristipuu külge on seotud punaseid paelakesi. Räpina kihelkonnas on ristimärgile lisaks naelaga kinnitatud ristamisi kuuseoksi. (RKM II 347, 426/7< Räpina khk.< M. Hiiemäe, 1980) Tänapäevases traditsioonis on need haruldased ja pole välistatud, et viimastel kümnenditel kajastub selles juba neomütoloogiline maailmakäsitlus, mis hoogustus Eesti ühiskonnas 1990. aastatel koos rahvusliku taasärkamisajaga.

\section{Ristipuudega suhtlemisest}

Soome asjaomases traditsioonis on paiguti tuntud spetsiaalseid vaimulikke itke ( $\mathrm{sm}$. karsikkovirsi), mida esitati enne ja pärast risti tegemist. (Vilkuna 1992: 107-108) Eesti matusekombestikus vastav traditsioon puudub.

Minu käsutuses on ainult üks suuline teade Rõuge kihelkonnast, kus öeldakse, et pärast risti lõikamist laskus naine põlvili ja luges "Meie Isa" palvet. Küll aga säilib omastel hilisem passiivne side ristipuuga.

[---] Ja ühe perekonna ristid tehakse ikka samale puule. Omma alati möödaminnes kaeda: Kae, siin on minu mehe ristikene... Läheb juure ja ikeb sääl. (ERA II 63, 146/7 (440) < Põlva khk.)

Ku ildampa matussõ pääl käüdäs, laskva vanainemiseq Rauskapalu vahel kiirusõ mahaq võtta ja kaessõ ristiq üle: tuu om tollõ, sjoo sjollõ uma, a tollõ umma jäl es näeki. (E. Saar M. Kõivupuule< Urvaste khk., 1995) 
MK: On sul rist meeles? AL: Ku mööda lähän, vaatan toda ära. (A. Leosk M. Kõivupuule< Põlva khk., 1995)

[---] Seda risti vaadati ja mäletati hiljem, kui sealt mööda mindi. (ERA II 298, 231/2(1)< Kambja khk., 1933)

Kus Kuressaare tee pöörab, olid keik puud ristisid täis. Iga pere jäuks oli puu. Nüüd on nee puud maha raiutud. Ühekorra läksime säält kaudu kirku, siis teised näitasid moole ka, koes meite pere puu on. (RKM II 2, 239 (46)< Kihelkonna khk., 1949)

\section{Ristipuud kirjanduses}

Lõuna-Eestist pärit kirjanike proosas ja luules on ristide lõikamise traditsioon samuti kajastamist leidnud. Pärnumaalt pärit Peet Vallaku novellis Relvad vastamisi (Vallak 1985: 77-96), mis nägi trükivalgust 1929. aastal samanimelises novellikogus (Vallak 1985< H. Puhvel 1985:30), tekkinud armastuskolmnurgas jääb kaotajaks Pärtel. Kaarel, kes on aastajagu tagasi matnud oma naise Liina, elab Pärtli naise Elluga salaelu. Saanud sellest teada, kuulutab Pärtel oma naise surnuks ja korraldab talle matused.

Ta pöördus nurmelt metsateele ja saabus Koopamäe juurde. Siin peatas ta hobuse, hüppas vankrist maha ja võttis taskust käänispeaga noa. Üheksa risti oli aegade jooksul lõigatud siia vanadesse kasetüvedesse: üheksa surnut oli siit Unnustest välja viidud inimpõlve jooksul. Üks rist oli neist koguni värske: Kaarli surnud naise Liina oma...

Tuul kahistas ülal võimsate kaskede lehti, ja Pärtel lõi noa ühte tüvesse, et lõigata kümnendat risti. Pika riba tõmbas ta vanasse krobelisse koorde, ent siis peatus käsi ja - tõmbas noa välja.

Kas rüvetada seda vana kommet, millest seni on hoolega kinni peetud? Kas lõigata kasetüvesse kümnes rist, kui kümnendana on mööda viidud vaid tühi puusärk?...

Ta ei rüvetanud seda vanemate kommet, ta jättis risti siiski lõikamata. (Vallak 1985:96)

Pertti Virtaranta avaldab trükis eesti ja soomekeelsed vestlused kirjanik Valev Uibopuuga (Virtaranta 1991). V. Uibopuu emapoolne suguvõsa on pärit Võrumaalt Kanepi kihelkonnast, isapoolne Tartu- ja Võrumaa piirilt Sangaste kihelkonnast Laatrest. Kirjanik ise sündis 19. okt. 1913 Urvaste kihelkonnas Õru metsavahi pojana ja on end nimetanud ise võrumaiseks kirjankuks. (Virtaranta 1991: 17) Vestlustes Virtarantga kõneldakse ka ristipuudest Kanepi kihelkonna kirikuteel. (Virtaranta 1991: 48-50) Samal teemal on Uibopuu mõtteid vahetanud Sarust (Hargla khk.) pärit Raimond Kolgaga: Ma kuulsin hiljem, et ka siin all Harglas - kolleeg ja sõber Raimond Kolk on rääkinud mulle - nendel oli ka siin, see on hoopis Läti piiri pääl, samasugune komme. Ja nendelgi oli ristpalu nimetus sellel metsal, ristipalu. Ta jutustas mulle üks kuu aega tagasi Stokholmis, et kirjutab just romaani, mis algab niisuguse stseeniga, nende ristide lõikamise stseeniga, matustega ühenduses. (Virtaranta 1991: 50) Siinkirjutajaga samast külast pärit kirjanik Raimond Kolk lahkus igaviku teele 3. 11. 1992. Kas ja kuipalju jõudis ta oma plaane realiseerida, on mulle teadmata.

\section{Kokkuvõtteks}

Võrreldes teiste peretraditsioonidega, näiteks pulmadega on matmiskombestik oma olemuselt konservatiivseim nähtus. Kogu matusetseremoonia on suunatud eelkõige elavate psühholoogilise stabiilsuse saavutamiseks aga ka turvatunde tagamiseks. Surmasse suhtutakse kas hirmu, õuduse ja aukartusega või soodsalt. Mõlemad suhtumised on üleminevad ja neid on raske piiritleda. (Kulmar 1994: 54)

Uku Masing on kirjutanud: See tähendab, et ka Eestis ei koheldud surnuid sõpradena, vaid olenditena, kes olid arvestamatud. Looritsal on õigus, et nende muutumine kurjemaks kui enne oli 
tingitud kuidagi ristiusu ja sellega germaani mõjust, kuid iial mitte säärases ulatuses, kui arvab tema. Samuti ei tule oletada, nagu eestlased enne seda ainult oleksid armastanud oma surnuid, vaid on päris usutav, et nad vihkasid neid teatavail juhtudel ennegi. (Masing 1995: 111-112)

Ristide lõikamise traditsioon siirderiituse osana sisaldab lisaks irrutusriitusele ka ettevaatusfunktsiooni (Vilkuna 1992: 165), et lahkunu ei saaks mingil moel tulla elavaid häirima.

Kas risti lõikamise traditsioon on määratud hääbumisele? Põhimõtteliselt saab nõustuda J. Vilkuna väitega, et kui surnuid ei saadeta enam kodust kalmistule, vaid lahkunu maetakse otse kabelist (spetsiaalselt ehitatud leinamajast) ja matused peetakse kirikukülas, siis hääbub ristipuude traditsioon ka Kagu-Eestis (Vilkuna 1991: 10).

Tänapäeva Eesti küla pole majanduslikult seesuguseks arenguks (veel?) valmis. Jõutakse pidada traditsionaalseid matuseid suhteliselt rikka toidulauaga, sest maal jätkub praegu toitu enam kui sularaha. Tõeliste traditsionaalsete matuste pidamine on ka prezhtiizhiküsimus. Põhja- ja Kesk-Eesti matustel käinud vanem Võrumaa inimene lausub sageli, et sääl es olõki medägi, aeti inne niisõma nigu pini auku. Matustega avaldatakse surnule viimast austust ja lugupidamist. Ajaloolise Võrumaa külade, alevite ja väikelinnade elukorraldust liigne tsiviliseeritus varakapitalistlikus Eestis niipea ei ohusta, pigem vastupidi - mahajäämus maal ähvardab tasahilju välja suretada nii talud-külad. Aga koos elukeskkonnaga hävivad ka tavad ja kombed.

Ristilõikamise tava on tauninud mõned sügavalt religioossed ja rohelise maailmavaatega inimesed, kelle arusaamade kohaselt on ristide lõikamine asjatu puude kahjustamine (kuigi nende perekond ise traditsiooni järgib). Samal põhjusel ei meeldi neile ka näiteks lõikelillede kinkimine ja lillede vaasi murdmine.( RKM II 467, 233< L. Pindmaa < Rõuge khk.)

Ristipuud säilitab Kagu-Eestis vähemalt kolme põlve talus kooselamise tava, aga samuti küla kui terviku ühtsete väljakujunenud väärtushinnangute eelistamine massikultuurile ja (nõukogude) ühiskonna poolt pakutule. Matusetalitus on vanemate inimeste sotsiaalse kontrolli all, tavade eiramist pannakse pahaks, see omakorda mõjutab matusekorraldajaid. Turvalisem on teha nii nagu ikka on tehtud.

Ma olin kaua Võrumaalt ära olnud, umbes seitse aastat... ja noh, ma siis küsisn teistelt, et mida tuleb teha, et kõik saaks tehtud viisipäraselt .... (A. Leosk M. Kõivupuule 1995< Põlva khk.)

Kas riste on lõigatud ka päris väikeste laste matuste puhul, pole teada.

Osa Kagu-Eestisse sisserännanud inimesi peab Võrumaa matusekombestikku ilusaks ja omapäraseks ja on selle üle võtnud, sealhulgas ka risti lõikamise tava.

Traditsiooni säilimise ja väärtustamise seisukohalt on positiivne, et osa suuremaid ristipuid on looduskaitse alla võetud. Mõned ristidega pedäjäd asuvad vahetult muistsete matmispaikadearheoloogiamälestiste kohal. Kuid arvestades traditsiooni arhailisust ja ainulaadsust, vääriksid veel mõnedki ristipuud ja ristimetsatukad (loodus? muinsus?)kaitse alla võtmist.

[---]kohapealsel rahval on kombeks ning siisejuurdunud harjumuseks sel teemal vaikida, vaikida kaljukindlalt, eriti veel kui koguja või uurija on võõras. (RKM II 47, 317/8 < E. Siil< Urvaste khk., 1955) 
Ebatäpne informatsioon mõjutab omakorda uurimistulemusi ja saadud teoreetiline üldistus ei pruugi osutuda alati objektiivseks.

PS. Võrumurdeliste tekstide edastamisel on autor lähtunud rahvusvahelise keelekomisjoni poolt 1995. aasta sügisel kinnitatud reeglitest. $\mathrm{q}=$ larüngalklusiil.

\section{Kirjandus}

Antiigileksikon. 2. Tallinn 1983.

Boecler, J. W; Kreutzwald, Fr. R. Der Ehsten abergläubische Gebräuche, Weisen und

Gewohnheiten. St.-Petersburg 1854.

EE 1995 = Eesti Entsüklopeedia. 8. Tallinn 1995.

Eisen, M. J. Esivanemate ohverdamised. Eesti mütoloogia. III. Tallinn 1920.

Eisen, M. J. Meie jõulud. Tallinn 1994.

Frazer, J. G. Zolotaja vetvj. Moskva, 1986.

Hiiemäe, M. Eesti rahvakalender. VII. Tallinn, 1995.

Juvas, M. Kuolema. Sana-ja asiateadustelu. Helsinki 1930.

Kulmar, T. Eesti muinasusundi hingefenomenoloogiast. Akadeemia 1992, nr. 7-9.

Kulmar, T. Üldine usundilugu I. Tartu 1994.

Kõivupuu, M. Minu unistuste Võrumaa. Kultuur ja Elu. 1991, nr. 10.

Kõivupuu, M. Võrokõstõ lugõmiseraamat. Tallinn 1993.

Laugaste, E. Eesti rahvaluuleteaduse ajalugu. Tallinn 1963.

Loorits, O. Grundzüge des Estnischen Volksglaubens. I. Lund 1949.

Loorits, O. Eesti rahvausundi maailmavaade. Tallinn 1990.

Masing, U. Eesti usund. Tartu 1995.

Moor, A. Puud Eesti rahvatraditsioonis. Magistritöö käsikiri. Tartu 1996.

Ränk, A. Etnograafia sõnaraamat. Tallinn 1995.

Vallak, P. Relvad vastamisi. Elu nullpunkt. Tallinn 1986.

Vaserik, A. (toim.). Esivanemate varandus. Tartu 1992.

Viires, A. Puud ja inimesed. Tallinn 1975.

Viires, A. Eesti rahvakultuuri leksikon. Tallinn 1995.

Vilkuna, J. Matka menneisyyteen. Konneveden Joulu. 1991.

Vilkuna, J. Suomalaiset vainajien karsikot ja ristipuut. Jyväskylä 1992.

Virtaranta, P. Keskusteluja Valev Uibopuun kanssa. Vestlusi Valev Uibopuuga. Helsinki 1991.

\section{Viidatud käsikirjalised allikad}

Eesti Kirjandusmuuseumi Rahvaluule Arhiivis:

E - M. J. Eiseni kogu 1880-1934.

EKRK - Tartu Ülikooli eesti kirjanduse ja rahvaluule kateedri kogu 1947- .

ERA - Eesti Rahvaluule Arhiivi kogu 1927-1944.

H - Jakob Hurda kogu 1860-1906.

RKM - Riikliku Kirjandusmuuseumi, hiljem TA Fr. R. Kreutzwaldi nim. Kirjandusmuuseumi kogu 1945-1995.

Eesti Rahva Muuseumi (ERM-i) Fotokogu. 
Autori tänu kuulub Tartu Kultuurkapitalile, kelle toetusel sai võimalikuks ristipuude filmimine ja kaardistamine ajaloolisel Võrumaal 1996. aasta veebruaris, samuti postuumselt operaator Ürgo Russakule, kellele see ekspeditsioon jäi üheks viimaseks tööks. 